\title{
FEEDBACK: Feminism and Racism
}

In this issue we are publishing a number of short articles and letters sent to us in response to Michèle Barrett and Mary McIntosh's article 'Ethnocentrism and Socialist-Feminist Theory' in Feminist Review No. 20 (1985). Some of these interventions also refer back to Many Voices, One Chant: Black Feminist Perspectives, Feminist Review No. 17 (1984) and to Floya Anthias and Nira Yuval-Davis's article 'Contextualizing Feminism - Gender, Ethnic and Class Divisions' in Feminist Review No. 15 (1983). The pieces printed here represent a wide range of positions on the theme of race and ethnicity. We feel that the promotion of such discussion is of vital importance for socialist feminism and welcome further contributions from readers to this debate.

Feminist Review Collective 